\section{Review of dose fractionation schemes for pontine glioma irradiation}

\section{Ferrat Dincoglan, Murat Beyzadeoglu, Omer Sager*, Selcuk Demiral, Bora Uysal, Hakan Gamsiz, Fatih Ozcan, Onurhan Colak and Bahar Dirican}

Department of Radiation Oncology; University of Health Sciences, Gulhane Medical Faculty, Ankara, Turkey
Received: 30 May, 2020

Accepted: 13 June, 2020

Published: 15 June, 2020

*Corresponding author: Dr. Omer Sager, MD, Associate Professor of Radiation Oncology, Department of Radiation Oncology, University of Health Sciences, Gulhane Medical Faculty, 06018, Etlik, Kecioren, Ankara Turkey, Tel: +90 312304 4683; Fax: +90 312304 4680; E-mail: omersager@gmail.com

Keywords: Diffuse intrinsic pontin glioma (DIPG); Radiation therapy (RT); Conventional fractionation; Hyperfractionation; Hypofractionation

ORCID: https://orcid.org/0000-0001-7866-2598

https://www.peertechz.com

\section{Check for updates}

\begin{abstract}
Brainstem tumors constitute approximately $10 \%$ to $15 \%$ of CNS neoplasms in the pediatric population, and most common of brainstem tumors is diffuse intrinsic pontine glioma (DIPG). Children with DIPG are typically diagnosed at the 5th to 10th years of their lives, with tumors being more frequently located in the pons rather than the midbrain or medulla oblongata. Symptomatology of patients may be severe and associated with compression of nuclei and tracts in the pons leading to cranial nerve dysfunctions. The wide spectrum of symptomatology may result in profound deterioration of the patients' quality of life, and management is required for symptomatic relief. Complete removal of DIPG is typically not achievable given the diffuse and infiltrating nature of the disease with significant risk of excessive toxicity associated with surgical interventions. Nevertheless, surgical biopsy may be considered as a technically feasible procedure for selected patients to allow for histopathological verification and acquisition of biological data to aid in decision making for management. Utility of chemotherapy, biological and targeted therapies is being actively investigated as a promising treatment strategy, however, there is still room for improvement for routine clinical use. Radiation therapy (RT) remains to be a principal management approach for DIPG. Herein, we provide a concise review of dose fractionation schemes for pontine glioma irradiation.
\end{abstract}

\section{Introduction}

Brain tumors in the pediatric population constitute a very frequent type of solid childhood cancers and a considerable part of all pediatric malignancies. These tumors are typically classified into supra and infratentorial with respect to their location. Another classification is based on age at diagnosis and includes congenital brain tumors, tumors of infancy period observed at younger than 1 year of age, and tumors observed in older children. Brain tumours account for about $20 \%$ of all childhood neoplasms [1-5]. Brainstem comprises a critical location for pediatric Central Nervous System (CNS) malignancies [5]. Critical parts of the brainstem include the medulla oblongata, pons, and the midbrain all of which are involved in critical functions of the human body [5].

Brainstem tumors constitute approximately $10 \%$ to $15 \%$ of CNS neoplasms in the pediatric population, and most common of brainstem tumors is Diffuse Intrinsic Pontine Glioma (DIPG)
[5-7]. Children with DIPG are typically diagnosed at the 5th to 10th years of their lives, with tumors being more frequently located in the pons rather than the midbrain or medulla oblongata [5-8]. Location at the midbrain and medulla oblongata may be associated with a relatively more favorable prognosis compared to pontine location with frequent expansion and diffuse infiltration of more than half of the pons [5-10]. DIPG are typically categorized as World Health Organization (WHO) grade III or IV tumors with typically an aggressive disease course and grim prognosis [5-11]. Median Overall Survival (OS) is typically in the range of 8 to 11 months, with a low OS rate of about $30 \%$ at 1 year, and less than $10 \%$ at 2 years [11].

Diagnosis of pontine gliomas is typically based on detailed history, clinical examination and presentation findings, comprehensive neurological evaluation, and neuroimaging with Magnetic Resonance Imaging (MRI) [5]. Using the clinical and imaging findings for diagnosis has been suggested to avoid 
the considerable risk of complications associated with biopsy $[12,13]$. However, advances in surgery may render stereotactic and liquid biopsies to be performed for selected patients [14-16]. Histopathological verification and an improved understanding of the biology of DIPG may pave the way for development of novel treatment paradigms including immunotherapeutic strategies to combat with this dreadful disease [4,7,15-18]. The H3K27M mutation has been identified in the majority of DIPGs, and advances in epigenetic targeting of transcriptional tendencies have put forth potential molecular targets which could be further investigated $[4,7,15-18]$.

MRI constitutes the imaging modality of choice for DIPG with unique imaging characteristics $[19,20]$. Conventional MRI comprises a noninvasive mode of diagnosis for DIPGs which are typically expansile and infiltrative tumors located at the pons frequently with lateral extentions to the middle cerebellar peduncles, caudally to medulla oblongata and cranially to midbrain; and MRI typically reveals a isointense or hypointense lesion on T1-weighted MRI and hyperintense lesion on T2weighted MRI with indistinct borders consistent with the infiltrative nature of DIPGS $[19,20]$. Exophytic growth into the prepontine cistern may be seen in some patients and the basillar artery may also be engulfed by the lesion [20]. DIPGs may typically demonstrate mild heterogeneous enhancement or no enhancement, nevertheless, increased enhancement or ring enhancement may be suggestive of poorer prognosis [2022].

Symptomatology of patients may be severe and associated with compression of nuclei and tracts in the pons leading to cranial nerve dysfunctions [5-8]. Headache, gait and visual disturbances, dysconjugate gaze and diplopia with abducens palsy, impaired alignment of the eyes, dysarthria, nausea and vomiting, impaired mobility and spasticity, Babinsky sign, weakness in legs and arms, facial weakness or asymmetry due to cranial nerve VII damage, behavioural alterations, impaired communication, and altered levels of consciousness may occur [5-8]. Gait, speech and coordination disturbances manifesting as ataxia, dysarthria, and dysmetria may be suggestive of multiple cranial neuropathies along with long tract and cerebellar signs referred to as the classical triad of DIPG [5$8,23-25]$. Hydrocephalus may also be observed in a small group of affected patients due to blockade of cerebrospinal fluid flow with dorsal tumor extention [7,23,24]. The wide spectrum of symptomatology may result in profound deterioration of the patients' quality of life, and management is required for symptomatic relief. Complete removal of DIPG is typically not achievable given the diffuse and infiltrating nature of the disease with significant risk of excessive toxicity associated with surgical interventions. Nevertheless, surgical biopsy may be considered for selected patients [4,7,15-18, 26-28]. Utility of chemotherapy, biological and targeted therapies is being actively investigated as a promising treatment strategy, however, there is still room for improvement for routine clinical use [29-31]. Radiation Therapy (RT) remains to be a principal management approach for DIPG. Herein, we provide a concise review of dose fractionation schemes for pontine glioma irradiation.

\section{Irradiation of pontine gliomas by use of conventional fractionation}

Conventionally fractionated RT (CFRT) has been traditionally utilized for management of pontine gliomas with the primary goal of achieving symptomatic relief and disease control. A total RT dose of 54 to $60 \mathrm{~Gy}$ is delivered over approximately 6 weeks with CFRT using a daily fraction dose of 1.8 to 2 Gy $[5,8,9,32-34]$. Use of steroids during the RT course may aid in management of symptoms due to peritumoral edema, typically with dose tapering after treatment completion. In a systematic review by Gallitto, et al. [33], CFRT constituted the majority of definitive RT series for DIPG management. Median OS with CFRT was 12 months whereas median OS was 10.2 months for hyperfractionated RT and 7.9 months for hypofractionated RT regimens [33]. Freese et al. [34] assessed outcomes of RT and subsequent irradiation in a study group of 26 patients with DIPG. Conventional fractionation was used as the dose fractionation scheme, and patients were treated using Intensity Modulated Radiation Therapy (IMRT) [34]. Reirradiation was utilized for 3 patients with a total dose of $20 \mathrm{~Gy}$ delivered again with conventional fractionation [34]. The authors concluded that advances in treatment techniques could allow for retreatment of patients after definitive management with RT [34].

\section{Irradiation of pontine gliomas by use of hyperfractiona- ted RT}

Rationale behind hyperfractionation includes delivering higher biologically equivalent doses of RT whilst avoiding treatment related adverse effects. In this context, several trials have focused on hyperfractionated RT schemes [35-42]. Mandell, et al. [42] conducted a phase III randomized controlled trial comparing hyperfractionated RT and CFRT fpr management of newly diagnosed diffuse intrinsic brainstem tumors. A total of 130 patients were enrolled, and no clear evidence of effect was observed on OS $[9,42]$. Considering the absence of evidence demonstrating the superiority of hyperfractionation, it seems prudent not to opt for hyperfractionated RT regimens which also put forward additional issues including logistics, patient convenience, and potential requirements for repeated anaesthesia $[5,9,33]$.

\section{Irradiation of pontine gliomas by use of hypofractiona- ted RT}

Given the limited life expectancy of patients with DIPG, hypofractionated RT regimens have been considered [4348]. Primary aim of hypofractionation is shortened overall treatment time compared to CFRT. However, no improvement in OS has been achieved with hypofractionation and even inferior outcomes have been reported [9,33,43-48]. In the systemic review by Gallitto et al. [33], mean median OS for hypofractionated RT series was 7.9 months with a mean 1-year OS rate of $\mathbf{2 8 . 8 \%}$. Nevertheless, hypofractionated RT regimens may offer decreased treatment burden on patients and their families. In this context, selected patients may be considered for hypofractionated RT regimens despite need for further supporting evidence [49]. 


\section{Reirradiation of pontine gliomas}

Despite the poor prognosis of DIPG with limited survival durations, reirradiation may be considered [34]. Reirradiation schemes may include CFRT as well as radiosurgical applications [34,50-52]. Comprehensive studies addressed the utility of reirradiation for DIPG [53-58]. Janssens, et al. analyzed the benefit and toxicity of reirradiation at first progression of DIPG [56]. They treated 31 children aged 2-16 years with DIPG at first progression with a reirradiation dose of 19.8 - 30 Gy [56]. Median overall survival was 13.7 months for patients receiving reirradiation, and the authors concluded that majority of DIPG patients responding to upfront RT may benefit from reirradiation with acceptable toxicity [56]. Massimino, et al. assessed the results of nimotuzumab and vinorelbine, RT and reirradiation for diffuse pontine glioma in childhood [57]. Twenty five patients were enrolled, and 11 out of 16 patients with local relapse received reirradiation to a dose of $19.8 \mathrm{~Gy}$ delivered over 11 days [57]. Median progression free survival was 8.5 months and median overall survival was 15 months [57]. The authors concluded that the treatment strategy should be further investigated in view of the interesting results [57]. Wolff et al. reported their experience on treatment of recurrent DIPG including reirradiation as part of management in 7 patients out of the total 31 patients [58]. The authors concluded that reirradiation should be tested in a prospective clinical study in view of the encouraging response rates [58].

Recent years have witnessed significant advances in radiation oncology with widespread adoption of contemporary RT strategies including Image Guided Radiation Therapy (IGRT), Intensity Modulated Radiation Therapy (IMRT), and Adaptive Radiation Therapy [59-65]. Radiosurgery in the form of Stereotactic Radiosurgery (SRS), Stereotactic Body Radiation Therapy (SBRT) and Hypofractionated Stereotactic Radiation Therapy (HFSRT) may be used for focused irradiation of several CNS disorders as well as several other tumors throughout the human body [66-100]. Rationale of radiosurgery includes highly focused delivery of high and ablative RT doses to well defined targets with optimal normal tissue sparing with stereotactic localization, robust immobilization, and steep dose gradients around the target. Nevertheless, there is relatively limited experience with this relatively newer radiotherapeutic strategy.

\section{Conclusions and future perspectives}

RT plays a major role in management of pontine gliomas. Given the limited life expectancy of patients with DIPG, RT may be utilized for achieving at least a transient stabilization of disease and improvement in symptoms and quality of life. Improved understanding of the biology of DIPG may allow for utilization of targeted therapies to achieve an improved therapeutic ratio for pontine gliomas.

\section{References}

1. Stiller CA, Nectoux J (1994) International incidence of childhood brain and spinal tumours. Int J Epidemiol 23: 458-464. Link: https://bit.ly/2Yzm3lx

2. Linabery AM, Ross JA (2008) Trends in childhood cancer incidence in the U.S. (1992-2004).Cancer 112: 416-432. Link: https://bit.ly/3d0d3er
3. Johnson KJ, Cullen J, Barnholtz-Sloan JS, Ostrom QT, Langer CE, et al. (2014) Childhood brain tumor epidemiology: a brain tumor epidemiology consortium review. Cancer Epidemiol Biomarkers Prev 23: 2716-2736. Link: https://bit.ly/2Yv7W0y

4. Pollack IF, Agnihotri S, Broniscer A (2019) Childhood brain tumors: current management, biological insights, and future directions. J Neurosurg Pediatr 23: 261-273. Link: https://bit.ly/2N769JX

5. Sager O, Dincoglan F, Demiral S, Uysal B, Gamsiz H, et al. (2018) Radiation Therapy (RT) for Diffuse Intrinsic Pontine Glioma (DIPG) in Children. Arch Can Res 6: 14. Link: https://bit.ly/3fpsiyT

6. Frazier JL, Lee J, Thomale UW, Noggle JC, Cohen KJ, et al. (2009) Treatment of diffuse intrinsic brainstem gliomas: failed approaches and future strategies. J Neurosurg Pediatr 3: 259-269. Link: https://bit.ly/3dWSQHK

7. Johung TB, Monje M (2017) Diffuse Intrinsic Pontine Glioma: New Pathophysiological Insights and Emerging Therapeutic Targets. Curr Neuropharmacol 15: 88-97. Link: https://bit.ly/3hl5UbU8.

8. Vanan MI, Eisenstat DD (2015) DIPG in children: What can we learn from the past?. Front Oncol 5: 237. Link: https://bit.ly/30FEtno

9. Hu X, Fang Y, Hui X, Jv Y, You C (2016) Radiotherapy for diffuse brainstem glioma in children and young adults. Cochrane Database Syst Rev 6: CD010439. Link: https://bit.ly/2UD0xv6

10. Infinger LK, Stevenson CB (2017) Re-Examining the Need for Tissue Diagnosis in Pediatric Diffuse Intrinsic Pontine Gliomas: A Review. Curr Neuropharmacol 15: 129-133. Link: https://bit.ly/2zsp52k

11. Hargrave D, Bartels U, Bouffet E (2006) Diffuse brainstem glioma in children: Critical review of clinical trials. Lancet Oncol 7: 241-248. Link: https://bit.ly/37r7yEa

12. Albright AL, Packer RJ, Zimmerman R, Rorke LB, Boyett J, et al. (1993) Magnetic resonance scans should replace biopsies for the diagnosis of diffuse brain stem gliomas: A report from the Children's Cancer Group Neurosurgery 33: 1026-1029. Link: https://bit.ly/37sS088

13. Epstein F, McCleary EL (1986) Intrinsic brain-stem tumors of childhood Surgical indications. J Neurosurg 64: 11-15. Link: https://bit.ly/3hot9lg

14. Lu VM, Power EA, Zhang L, Daniels DJ (2019) Liquid biopsy for diffuse intrinsic pontine glioma: an update. J Neurosurg Pediatr 1-8. Link: https://bit.ly/2MWfcwU

15. Williams JR, Young CC, Vitanza NA, McGrath M, Feroze AH, et al. (2020) Progress in diffuse intrinsic pontine glioma: advocating for stereotactic biopsy in the standard of care. Neurosurg Focus 48: E4. Link: https://bit.ly/3d4TaTC

16. Vitanza NA, Monje M (2019) Diffuse Intrinsic Pontine Glioma: From Diagnosis to Next-Generation Clinical Trials. Curr Treat Options Neurol 21: 37. Link: https://bit.ly/30FiLjs

17. Rashed WM, Maher E, Adel M, Saber O, Zaghloul MS (2019) Pediatric diffuse intrinsic pontine glioma: where do we stand?. Cancer Metastasis Rev 38: 759-770. Link: https://bit.ly/3fprutR

18. Cohen KJ, Jabado N, Grill J (2017) Diffuse intrinsic pontine gliomascurrent management and new biologic insights. Is there a glimmer of hope? Neuro Oncol 19: 1025-1034. Link: https://bit.ly/2MW9n2I

19. Barkovich AJ, Krischer J, Kun LE, Packer R, Zimmerman RA, et al. (1991) Brain stem gliomas: A classification system based on magnetic resonance imaging Pediatr Neurosurg 16: 73-83. Link: https://bit.ly/2UFhYem

20. TisnadoJ, Young R, Peck KK, Haque S (2016) Conventional and Advanced Imaging of Diffuse Intrinsic Pontine Glioma. J Child Neurol 31: 1386-1393. Link: https://bit.ly/2AnxBAn

21. Jansen MH, Veldhuijzen van Zanten SE, Sanchez Aliaga E, Heymans MW, Warmuth-Metz M, et al. (2015) Survival prediction model of children with diffuse intrinsic pontine glioma based on clinical and radiological criteria. Neuro Oncol 17: 160-166. Link: https://bit.ly/2YvTVj9 
22. Poussaint TY, Kocak M, Vajapeyam S, Packer RI, Robertson RL, et al. (2011) MRI as a central component of clinical trials analysis in brainstem glioma: a report from the Pediatric Brain Tumor Consortium (PBTC). Neuro Oncol 13: 417-427. Link: https://bit.ly/3hqKpq4

23. Donaldson SS, Laningham F, Fisher PG (2006) Advances toward an understanding of brainstem gliomas. J Clin Oncol 24: 1266-1272. Link: https://bit.ly/2UW29jN

24. Schroeder KM, Hoeman CM, Becher OJ (2014) Children are not just little adults: recent advances in understanding of diffuse intrinsic pontine glioma biology. Pediatr Res 75: 205-209. Link: https://go.nature.com/37pn8QZ

25. Panitch ES, Berg BO (1970) Brain stem tumors of childhood and adolescence. Am J Dis Child 119: 465-472. Link: https://bit.ly/37rVsuP

26. Gupta N, Goumnerova LC, Manley P, Chi SN, Neuberg D, et al. (2018) Prospective feasibility and safety assessment of surgical biopsy for patients with newly diagnosed diffuse intrinsic pontine glioma. Neuro Oncol 20: 1547 1555. Link: https://bit.ly/2YOApfL

27. Wang ZJ, Rao L, Bhambhani K, Miller K, Poulik J, et al. (2015) Diffuse intrinsic pontine glioma biopsy: a single institution experience. Pediatr Blood Cancer 62: 163-165. Link: https://bit.ly/3e2ex9o

28. Walker DA, Liu J, Kieran M, Jabado N, Picton S, et al. (2013) A Multi-Disciplinary Consensus Statement Concerning Surgical Approaches to Low-Grade, HighGrade Astrocytomas and Diffuse Intrinsic Pontine Gliomas in Childhood (CPN Paris 2011) Using the Delphi Method. Neuro Oncol 15: 462-468. Link: https://bit.ly/2MT1P0B

29. Gokce-Samar Z, Beuriat PA, Faure-Conter C, Carrie C, Chabaud S, et al. (2016) Pre-radiation chemotherapy improves survival in pediatric diffuse intrinsic pontine gliomas. Childs Nerv Syst 32: 1415-1423. Link: https://bit.ly/30ESS3e

30. Gwak HS, Park HJ (2017) Developing chemotherapy for diffuse pontine intrinsic gliomas (DIPG). Crit Rev Oncol Hematol 120: 111 119. Link: https://bit.ly/37oeja3

31. Kebudi R, Cakir FB (2013) Management of diffuse pontine gliomas in children: recent developments. Paediatr Drugs 15: 351-362. Link: https://bit.ly/2YxBJWs

32. Yoshida K, Sulaiman NS, Miyawaki D, Ejima Y, Nishimura H, et al. (2017) Radiotherapy for brainstem gliomas in children and adults: A single-institution experience and literature review. Asia Pac J Clin Oncol 13: e153-e160. Link: https://bit.ly/2AuT7Ty

33. Gallitto M, Lazarev S, Wasserman I, Stafford JM, Wolden SL, et al. (2019) Role of Radiation Therapy in the Management of Diffuse Intrinsic Pontine Glioma: A Systematic Review. Adv Radiat Oncol 4: 520-531. Link: https://bit.ly/30CJ0a0

34. Freese C, Takiar V, Fouladi M, DeWire M, Breneman J, et al. (2017) Radiation and subsequent reirradiation outcomes in the treatment of diffuse intrinsic pontine glioma and a systematic review of the reirradiation literature. Pract Radiat Oncol 7: 86-92. Link: https://bit.ly/30DUpqf

35. Marcus KJ, Dutton SC, Barnes P, Coleman CN, Pomeroy SL, et al. (2003) A phase I trial of etanidazole and hyperfractionated radiotherapy in children with diffuse brainstem glioma. Int J Radiat Oncol Biol Phys 55: 1182-1185. Link: https://bit.ly/2B2Ay9h

36. Allen J, Siffert J, Donahue B, Nirenberg A, Jakacki R, et al. (1999) A phase I/II study of carboplatin combined with hyperfractionated radiotherapy for brainstem gliomas. Cancer 86: 1064-1069. Link: https://bit.ly/2zx5HRW

37. Packer RJ, Prados M, Phillips P, Nicholson HS, Boyett JM, et al. (1996) Treatment of children with newly diagnosed brain stem gliomas with intravenous recombinant beta-interferon and hyperfractionated radiation therapy: A children's cancer group phase I/II study. Cancer 77: 2150-2156. Link: https://bit.ly/30Abr8F

38. Packer RJ, Boyett JM, Zimmerman RA, Albright AL, Kaplan AM, et al. (1994) Outcome of children with brain stem gliomas after treatment with $7800 \mathrm{cGy}$ of hyperfractionated radiotherapy. A Children's cancer group phase I/II trial Cancer 74: 1827-1834. Link: https://bit.ly/2YthHw8
39. Packer RJ, Boyett JM, Zimmerman RA, Rorke LB, Kaplan AM, et al. (1993) Hyperfractionated radiation therapy (72 Gy) for children with brain stem gliomas. A childrens cancer group phase I/II Trial. Cancer 72: 1414-1421. Link: https://bit.ly/2AovE6N

40. Kretschmar CS, Tarbell NJ, Barnes PD, Krischer JP, Burger PC, et al. (1993) Pre-irradiation chemotherapy and hyperfractionated radiation therapy 66 Gy for children with brain stem tumors: A phase II study of the Pediatric Oncology Group, Protocol 8833. Cancer 72: 1404-1413. Link: https://bit.ly/3cT8RNq

41. Freeman CR, Krischer JP, Sanford RA, Cohen ME, Burger PC, et al. (1993) Final results of a study of escalating doses of hyperfractionated radiotherapy in brain stem tumors in children: A Pediatric Oncology Group study. Int J Radiat Oncol Biol Phys 27: 197-206. Link: https://bit.ly/2AwAgHS

42. Mandell LR, Kadota R, Freeman C, Douglass EC, et al. (1999) There is no role for hyperfractionated radiotherapy in the management of children with newly diagnosed diffuse intrinsic brainstem tumors: results of a Pediatric Oncology Group phase III trial comparing conventional vs. hyperfractionated radiotherapy. Int J Radiat Oncol Biol Phys 43: 959-964. Link: https://bit.ly/3dWQDvW

43. Janssens GO, Gidding CE, Van Lindert EJ, Oldenburger FR, Erasmus CE, et al. (2009) The role of hypofractionation radiotherapy for diffuse intrinsic brainstem glioma in children: A pilot study. Int J Radiat Oncol Biol Phys 73: 722-726. Link: https://bit.ly/2AnvFI7

44. Negretti L, Bouchireb K, Levy-Piedbois C, Habrand JL, Dhermain F, et al. (2011) Hypofractionated radiotherapy in the treatment of diffuse intrinsic pontine glioma in children: A single institution's experience. J Neurooncol 104: 773777. Link: https://bit.ly/3hs4mwH

45. Zaghloul MS, Eldebawy E, Ahmed S, Mousa AG, Amin A, et al. (2014) Hypofractionated conformal radiotherapy for pediatric diffuse intrinsic pontine glioma (DIPG): A randomized controlled trial. Radiother Oncol 111 35-40. Link: https://bit.ly/2MSDF6e

46. Hankinson TC, Patibandla MR, Green A, Hemenway M, Foreman N, et al. (2016) Hypofractionated radiotherapy for children with diffuse intrinsic pontine gliomas. Pediatr Blood Cancer 63: 716-718. Link: https://bit.ly/2UFe8BP

47. Hayashi A, Ito E, Omura M, Aida N, Tanaka M, et al. (2020) Hypofractionated radiotherapy in children with diffuse intrinsic pontine glioma. Pediatr Int 62 47-51. Link: https://bit.ly/30C6zQb

48. Izzuddeen Y, Gupta S, Haresh KP, Sharma D, Giridhar $P$, et al (2020) Hypofractionated radiotherapy with temozolomide in diffuse intrinsic pontine gliomas: a randomized controlled trial. J Neurooncol 146: 91-95. Link: https://bit.ly/3e1tus7

49. Zaghloul MS, Akoush H, Ahmed S (2018) Hypofractionated radiation for pediatric diffuse intrinsic pontine glioma (DIPG): Younger children have better survival. Int J Radiat Oncol Biol Phys 101: 1008-1009. Link: https://bit.ly/3fo94tQ

50. Lassaletta A, Strother D, Laperriere N, Hukin J, Vanan Ml, et al. (2018) Reirradiation in patients with diffuse intrinsic pontine gliomas: The Canadian experience. Pediatr Blood Cancer 65: e26988. Link: https://bit.ly/2MWA5II

51. Yen CP, Sheehan J, Steiner M, Patterson G, Steiner L (2007) Gamma knife surgery for focal brainstem gliomas. J Neurosurg 106: 8-17. Link: https://bit.ly/3fm2TGt

52. Fuchs I, Kreil W, Sutter B, Papaethymiou G, Pendl G (2002) Gamma knife radiosurgery of brainstem gliomas. Acta Neurochir Suppl 84: 85-90. Link: https://bit.ly/3fnO9qq

53. Ermoian R, MacDonald S, Laack NNI, Baldini E, Breneman J (2019) Reirradiation in Pediatric Patients With Recurrent Brain Tumors: A Last Hope, But One With Greatly Feared Consequences. Int J Radiat Oncol Biol Phys 103: 1-4. Link: https://bit.ly/2XWjbzW

54. Kline C, Liu SJ, Duriseti S, Banerjee A, Nicolaides T, et al. (2018) Reirradiation and PD-1 inhibition with nivolumab for the treatment of recurrent diffuse intrinsic pontine glioma: a single-institution experience. J Neurooncol 140 629-638.

Citation: Dincoglan F, Beyzadeoglu M, Sager O, Demiral S, Uysal B, et al. (2020) Review of dose fractionation schemes for pontine glioma irradiation. J Surg Surgical Res 6(1): 73-078.DOI: https://dx.doi.org/10.17352/2455-2968.000101 
55. Fontanilla HP, Pinnix CC, Ketonen LM, Woo SY, Vats TS, et al. (2012) Palliative re-irradiation for progressive diffuse intrinsic pontine glioma. Am J Clin Oncol 35: 51-57. Link: https://bit.ly/3cSk6FW

56. Janssens GO, Gandola L, Bolle S, Mandeville H, Ramos-Albiac M, et al. (2017) Survival benefit for patients with diffuse intrinsic pontine glioma (DIPG) undergoing re-irradiation at first progression: A matched-cohort analysis on behalf of the SIOP-E-HGG/DIPG working group. Eur J Cancer 73: 38-47. Link: https://bit.ly/3hz8YBs

57. Massimino M, Biassoni V, Miceli R, Schiavello E, Warmuth-Metz $M$, et al. (2014) Results of nimotuzumab and vinorelbine, radiation and re-irradiation for diffuse intrinsic pontine glioma. J Neurooncol 118: 305-312. Link: https://bit.ly/3fjpL9r

58. Wolff JE, Rytting ME, Vats TS, Zage PE, Ater JL, et al. (2012) Treatment of Recurrent Diffuse Intrinsic Pontine Glioma: The MD Anderson Cancer Center Experience. J Neurooncol 106: 391-397. Link: https://bit.ly/37ok0EX

59. Sager O, Beyzadeoglu M, Dincoglan F, Oysul K, Kahya YE, et al. (2012) Evaluation of active breathing control-moderate deep inspiration breath-hold in definitive non-small cell lung cancer radiotherapy. Neoplasma 59: 333-340. Link: https://bit.ly/3cVtnNh

60. Dincoglan F, Beyzadeoglu M, Sager O, Oysul K, Kahya YE, et al. (2013) Dosimetric evaluation of critical organs at risk in mastectomized left-sided breast cancer radiotherapy using breath-hold technique. Tumori 99: 76-82. Link: https://bit.ly/37o5Fs4

61. Uysal B, Beyzadeoğlu M, Sager O, Dinçoğlan F, Demiral S, et al. (2013) Dosimetric evaluation of intensity modulated radiotherapy and 4-field 3-d conformal radiotherapy in prostate cancer treatment. Balkan Med J 30: 54 57. Link: https://bit.ly/2B41WDQ

62. Sager O, Beyzadeoglu M, Dincoglan F, Demiral S, et al. (2015) Adaptive splenic radiotherapy for symptomatic splenomegaly management in myeloproliferative disorders. Tumori 101: 84-90. Link: https://bit.ly/37pzxnS

63. Sager O, Dincoglan F, Uysal B, Demiral S, Gamsiz H, Beyzadeoglu M (2017) Splenic Irradiation: A Concise Review of the Literature. J App Hem BI Tran 1 101. Link: https://bit.ly/3hoOtas

64. Sager O, Dincoglan F, Uysal B, Demiral S, Gamsiz H, et al. (2018) Evaluation of adaptive radiotherapy (ART) by use of replanning the tumor bed boost with repeated computed tomography (CT) simulation after whole breast irradiation (WBI) for breast cancer patients having clinically evident seroma. Jpn J Radio 36: 401-406. Link: https://bit.ly/2XYulV6

65. Sager O, Dincoglan F, Demiral S, Uysal B, Gamsiz H, et al. (2019) Breathing adapted radiation therapy for leukemia relapse in the breast: $A$ case report World J Clin Oncol 10: 369-374. Link: https://bit.ly/2UEbcWk

66. Sirin S, Oysul K, Surenkok S, Sager O, Dincoglan F, et al. (2011) Linear accelerator-based stereotactic radiosurgery in recurrent glioblastoma: A single center experience. Vojnosanit Pregl 68: 961-966. Link: https://bit.ly/3hqfBGb

67. Dincoglan F, Beyzadeoglu M, Sager O, Oysul K, Sirin S, et al. (2012) Imageguided positioning in intracranial non-invasive stereotactic radiosurgery for the treatment of brain metastasis. Tumori 98: 630-635. Link: https://bit.ly/2BOtOZA

68. Dincoglan F, Sager O, Gamsiz H, Demiral S, Uysal B, et al. (2012) Management of arteriovenous malformations by stereotactic radiosurgery: A single center experience. UHOD-Uluslararasi Hematoloji Onkoloji Dergisi 22: 107-112. Link: https://bit.ly/37qq3Zp

69. Surenkok S, Sager O, Dincoglan F, Gamsiz H, Demiral S, et al. (2012) Stereotactic radiosurgery in pituitary adenomas: A single center experience." UHOD-Uluslararasi Hematoloji Onkoloji Dergisi 22: 255-260. Link: https://bit.ly/3hlyUQJ

70. Dincoglan F, Sager O, Gamsiz H, Uysal B, Demiral S, et al. (2012) Stereotactic radiosurgery for intracranial tumors: A single center experience. Gulhane Med J 54: 190-198. Link: https://bit.ly/3cYmv1J
71. Sager O, Beyzadeoglu M, Dincoglan F, Demiral S, Uysal B, et al. (2013) Management of vestibular schwannomas with linear accelerator-based stereotactic radiosurgery: A single center experience. Tumori 99: 617-622. Link: https://bit.ly/2MUJpfT

72. Demiral S, Beyzadeoglu M, Uysal B, Oysul K, et al. (2013) Evaluation of stereotactic body radiotherapy (SBRT) boost in the management of endometrial cancer. Neoplasma 60: 322-327. Link: https://bit.ly/2XWslwe

73. Demiral S, Dincoglan F, Sager O, Gamsiz H, Uysa B, et al. (2016) Hypofractionated stereotactic radiotherapy (HFSRT) for who grade anterior clinoid meningiomas (ACM). Jpn J Radiol 34: 730-737. Link: https://bit.ly/2XYXBLq

74. Dincoglan F, Beyzadeoglu M, Sager O, Uysal B, et al. (2013) Evaluation of linear accelerator-based stereotactic radiosurgery in the management of meningiomas: a single center experience. J BUON 18 717-722. Link: https://bit.ly/3cZIYLM

75. Sager O, Beyzadeoglu M, Dincoglan F, Uysal B, Gamsiz H, et al. (2014) Evaluation of linear accelerator (LINAC)-based stereotactic radiosurgery (SRS) for cerebral cavernous malformations: a 15-year single-center experience. Ann Saudi Med 34: 54-58. Link: https://bit.ly/3fejWtY

76. Sager O, Beyzadeoglu M, Dincoglan F, Gamsiz H, Demiral S, et al. (2014) Evaluation of linear accelerator-based stereotactic radiosurgery in the management of glomus jugulare tumors. Tumori 100: 184-188. Link: https://bit.ly/3dZGeQ7

77. Gamsiz H, Beyzadeoglu M, Sager O, Dincoglan F, Demiral S, et al. (2014) Management of pulmonary oligometastases by stereotactic body radiotherapy. Tumori 100: 179-183. Link: https://bit.ly/3hkihoN

78. Dincoglan F, Sager O, Gamsiz H, Uysal B, Demiral S, et al. (2014) Management of patients with $\geq 4$ brain metastases using stereotactic radiosurgery boost after whole brain irradiation. Tumori 100: 302-306. Link: https://bit.ly/30C2viV

79. Demiral S, Beyzadeoglu M, Sager O, Dincoglan F, Gamsiz H, et al. (2014) Evaluation of Linear Accelerator (Linac)-Based Stereotactic Radiosurgery (Srs) for the Treatment of Craniopharyngiomas. UHOD-Uluslararasi Hematoloj Onkoloji Dergisi 24: 123-129. Link: https://bit.ly/3hq6Vzm

80. Gamsiz H, Beyzadeoglu M, Sager O, Demiral S, Dincoglan $F$, et al. (2015) Evaluation of stereotactic body radiation therapy in the management of adrenal metastases from non-small cell lung cancer. Tumori 101: 98-103. Link: https://bit.ly/3ffjlYU

81. Sager O, Dincoglan F, Beyzadeoglu M (2015) Stereotactic radiosurgery of glomus jugulare tumors: current concepts, recent advances and future perspectives. CNS Oncol 4: 105-114. Link: https://bit.ly/3fhelOf

82. Dincoglan F, Beyzadeoglu M, Sager O, Demiral S, Gamsiz H, et al. (2015) Management of patients with recurrent glioblastoma using hypofractionated stereotactic radiotherapy. Tumori 101: 179-184. Link: https://bit.ly/3hnhD9L

83. Demiral S, Dincoglan F, Sager O, Gamsiz H, Uysal B, et al. (2016) Hypofractionated stereotactic radiotherapy (HFSRT) for who grade I anterior clinoid meningiomas (ACM). Jpn J Radiol 34: 730-737. Link: https://bit.ly/2XYXBLq

84. Dincoglan F, Sager O, Demiral S, Uysal B, Gamsiz H, et al. (2017) Radiosurgery for recurrent glioblastoma: a review article. Neurol Disord Therap 1: 1-5.

85. Demiral S, Dincoglan F, Sager O, Uysal B, Gamsiz H, et al. (2018) Contemporary Management of Meningiomas with Radiosurgery. Int J Radiol Imaging Techno 4: 041. Link: https://bit.ly/3fg295y

86. Dincoglan F, Sager O, Uysal B, Demiral S, Gamsiz H, et al. (2019) Evaluatıon of hypofractionated stereotactıc radıotherapy (HFSRT) to the resectıon cavity after surgıcal resectıon of braın metastases: A sıngle center experıence. Indian J Cancer 56: 202-206. Link: https://bit.ly/2UDoH8s

87. Dincoglan F, Sager O, Demiral S, Gamsiz H, Uysal B, et al. (2019) Fractionated stereotactic radiosurgery for locally recurrent brain metastases after failed stereotactic radiosurgery. Indian J Cancer 56: 151-156. Link: https://bit.ly/3fn3asy

Citation: Dincoglan F, Beyzadeoglu M, Sager O, Demiral S, Uysal B, et al. (2020) Review of dose fractionation schemes for pontine glioma irradiation. J Surg Surgical Res 6(1): 73-078.DOI: https://dx.doi.org/10.17352/2455-2968.000101 
88. Demiral S, Sager O, Dincoglan F, Beyzadeoglu M (2019) Assessment of Computed Tomography (CT) And Magnetic Resonance Imaging (MRI) Based Radiosurgery Treatment Planning for Pituitary Adenomas. Canc Therapy \& Oncol Int J 13: 555857. Link: https://bit.ly/37xB0Zl

89. Beyzadeoglu M, Sager O, Dincoglan F, Demiral S (2019) Evaluation of Target Definition for Stereotactic Reirradiation of Recurrent Glioblastoma. Arch Can Res 7: 3 .

90. Sager O, Dincoglan F, Demiral S, Beyzadeoglu M (2019) Evaluation of Radiosurgery Target Volume Determination for Meningiomas Based on Computed Tomography (CT) And Magnetic Resonance Imaging (MRI). Cancer Sci Res Open Access 5: 1-4. Link: https://bit.ly/30AeSw5

91. Dincoglan F, Sager O, Demiral S, Beyzadeoglu M (2019) Multimodality Imaging for Radiosurgical Management of Arteriovenous Malformations. Asian Journal of Pharmacy, Nursing and Medical Sciences 7: 7-12. Link: https://bit.ly/2MUF6RQ

92. Demiral S, Sager O, Dincoglan F, Beyzadeoglu M (2019) Assessment of target definition based on Multimodality imaging for radiosurgical Management of glomus jugulare tumors (GJTs). Cancer Ther Oncol Int J 15: 555-909. Link: https://bit.ly/3hvPde7

93. Sager O, Dincoglan F, Demiral S, Gamsiz H, Uysal B, et al. (2019) Utility of Magnetic Resonance Imaging (Imaging) in Target Volume Definition for Radiosurgery of Acoustic Neuromas. Int $\mathrm{J}$ Cancer Clin Res 6: 119. Link: https://bit.ly/2YvdacB

94. Sager O, Dincoglan F, Demiral S, Gamsiz H, Uysal B, et al. (2019) Evaluation of the Impact of Magnetic Resonance Imaging (MRI) on Gross Tumor Volume (GTV) Definition for Radiation Treatment Planning (RTP) of Inoperable High
Grade Gliomas (HGGs). Concepts Magnetic Resonance Part A 2019: 1-7. Link: https://bit.ly/3flLDRL

95. Demiral S, Sager O, Dincoglan F, Uysal B, Gamsiz H, et al. (2018) Evaluation of Target Volume Determination for Single Session Stereotactic Radiosurgery (SRS) of Brain Metastases. Canc Therapy Oncol Int J 12: 555848. Link: https://bit.ly/2MXRS1K

96. Sager O, Demiral S, Dincoglan F, Beyzadeoglu M (2020) Target Volume Definition for Stereotactic Radiosurgery (SRS) Of Cerebral Cavernous Malformations (CCMs). Canc Therapy Oncol Int J 15: 555917. Link: https://bit.ly/3eaCwD2

97. Dincoglan F, Demiral S, Sager O, Beyzadeoglu M (2020) Utility of Multimodality Imaging Based Target Volume Definition for Radiosurgery of Trigeminal Neuralgia: An Original Article. Biomed J Sci Tech Res 26: 19728-19732. Link: https://bit.ly/3fxhyin

98. Dincoglan F, Beyzadeoglu M, Sager O, Demiral S, Uysal B, et al. (2020) A Concise Review of Irradiation for Temporal Bone Chemodectomas (TBC). Arch Otolaryngol Rhinol 6: 016-020. Link: https://bit.ly/3dZ4WQA

99. Sager O, Beyzadeoglu M, Dincoglan F, Demiral S, Gamsiz H, et al. (2020) Multimodality management of cavernous sinus meningiomas with less extensive surgery followed by subsequent irradiation: Implications for an improved toxicity profile. J Surg Surgical Res 6: 056-061.

100. Beyzadeoglu M, Sager O, Dincoglan F, Demiral S, Uysal B, et al. (2020) Single Fraction Stereotactic Radiosurgery (SRS) versus Fractionated Stereotactic Radiotherapy (FSRT) for Vestibular Schwannoma (VS). J Surg Surgical Res 6: 062-066.
Discover a bigger Impact and Visibility of your article publication with Peertechz Publications
Highlights

* Signatory publisher of ORCID

* Signatory Publisher of DORA (San Francisco Declaration on Research Assessment)

* Articles archived in worlds' renowned service providers such as Portico, CNKI, AGRIS, TDNet, Base (Bielefeld University Library), CrossRef, Scilit, J-Gate etc.

* Journals indexed in ICMJE, SHERPA/ROMEO, Google Scholar etc.

- OAI-PMH (Open Archives Initiative Protocol for Metadata Harvesting)

* Dedicated Editorial Board for every journal

* Accurate and rapid peer-review process

* Increased citations of published articles through promotions

* Reduced timeline for article publication

Submit your articles and experience a new surge in publication services (https://www.peertechz.com/submission).

Peertechz journals wishes everlasting success in your every endeavours.

Copyright: (c) 2020 Dincoglan F, et al. This is an open-access article distributed under the terms of the Creative Commons Attribution License, which permits unrestricted use, distribution, and reproduction in any medium, provided the original author and source are credited. 